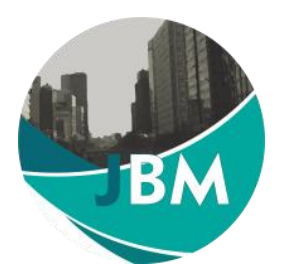

\title{
Persaingan Usaha Warung Tradisional dengan Toko Modern
}

Submitted Date:

12 Februari 2021

Accepted Date:

30 April 2021
Ainun Mardhiyah

Universitas Sumatera Utara

mardhiyahainun26@yahoo.co.id

Feby Aulia Safrin

Universitas Sumatera Utara

\section{Sugested Citation:}

Tri Joko Utomo. (2011). Persaingan Bisnis Ritel: Tradisional VS Modern (The Competition of Retail Business: Traditional vs Modern)). Jurnal: Fokus Ekonomi, Vol.6, No.1

\section{Abstract:}

The development of modern retail activities in Indonesia is currently experiencing rapid development. The types of retail trade are divided into two, namely modern retail such as supermarkets, hypermarts and minimarkets and others, while traditional retail, namely traditional stalls that are managed privately, may also absorb workers. This research was conducted in Medan City, especially in Medan Helvetia District. This research was conducted to the owners of traditional stalls with the aim of knowing what factors can affect business competition between traditional stalls and modern shops. The Medan Helvetia District area was used as the research location because Helvetia District is one of the sub-districts in Medan City where most of the residents live in the retail business (in this case traditional stalls). The method or approach used in this research is descriptive with a qualitative approach. The results obtained are the factors that influence business competition between traditional stalls and modern shops, namely price, location, service and product completeness. The existence of modern shops has no effect on traditional stalls because they pay attention to competitive strategies, namely by paying attention to price, location, service and product completeness.

Keywords: competitive strategy, modern shop, traditional stall

\section{Abstrak:}

Perkembangan kegiatan ritel modern di Indonesia saat ini mengalami perkembangan secara pesat. Jenis perdagangan ritel terbagi dua, yaitu ritel modern seperti supermarket, hypermart dan minimarket dan lain-lain, sedangkan ritel tradisional yaitu warung tradisional yang dikelola secara pribadi yang tidak menutup kemungkinan dapat juga menyerap tenaga kerja. Penelitian ini dilakukan di Kota Medan khususnya di Kecamatan Medan Helvetia. Penelitian ini dilakukan kepada para pemilik usaha warung tradisional dengan tujuan mengetahui faktor- faktor apa saja yang dapat mempengaruhi persaingan usaha antara warung tradisional dengan toko modern. Wilayah Kecamatan Medan Helvetia dijadikan lokasi penelitian dikarenakan Kecamatan Helvetia merupakan salah satu Kecamatan di Kota Medan yang sebagian penduduknya bermata pencaharian bisnis ritel (dalam hal ini warung tradisional). Metode atau pendekatan yang digunakan dalam penelitian ini adalah deskriptif dengan pendekatan kualitatif. Hasil yang diperoleh yaitu faktor-faktor yang mempengaruhi persaingan usaha antara warung tradisional dengan toko modern yaitu harga, lokasi, pelayanan dan kelengkapan produk. Keberadaan toko modern tidak berpengaruh terhadap warung tradisional karena mereka memperhatikan strategi bersaing, yaitu dengan memperhatikan harga, lokasi, pelayanan dan kelengkapan produk.

Kata Kunci: strategi bersaing, warung tradisional, toko modern

JEL Classification : L81, 



\section{Latar Belakang}

Perkembangan kegiatan ritel modern di Indonesia saat ini mengalami perkembangan secara pesat, bahkan kegiatan ritel modern ini sudah memasuki wilayah pemukiman yang dekat dengan masyarakat. Pesatnya pertumbuhan toko modern di Indonesia ini menyebar diseluruh Wilayah di Indonesia. Di mana juga banyak wilayah di Indonesia yang penduduknya berjualan ritel tradiisonal, di mana toko modern yang akan menjadi pesaingnya.

Jenis perdagangan ritel terbagi dua, yaitu ritel modern seperti supermarket, hypermart dan minimarket dan lain-lain, sedangkan ritel tradisional yaitu warung tradisional yang berada di pasar tradisional maupun yang dikelola secara pribadi dengan modal yang tidak besar dan usaha ini merupakan bisnis keluarga yang tidak menutup kemungkinan dapat juga menyerap tenaga kerja.

Sutikno (2009) dalam penelitiannya menyatakan preferensi konsumen terhadap pasar tradisional dan pasar modern dikategorikan pada preferensi konsumen terhadap kelengkapan barang, kepastian harga, kualitas barang, kesopanan pedagang, keramahan pedagang, kesigapan pedagang, keamanan pasar, kelengkapan fasilitas, kebersihan dan kenyamanan pasar.

Dengan berkembangnya ritel modern seperti minimarket membuat para pengusaha warung tradisional harus dapat bersaing dengan para pengusaha ritel modern ini agar para konsumen tidak beralih berbelanja ke minimarket. Usaha eceran atau ritel bisa dipahami sebagai semua kegiatan jual beli yang terlibat di dalam penjualan barang atau jasa secara langsung kepada konsumen akhir untuk penggunaan pribadi dan bukan penggunaan bisnis (Utami, 2006).

Bisnis ritel sendiri tidak harus melibatkan penggunaan suatu toko. Bentuknya pun dapat berupa pesanan pembelian lewat telepon atau surat, penjualan langsung, dan sebagainya. Pemasaran eceran tidak hanya dapat digunakan oleh sebuah pengecer saja, tetapi juga bisa oleh produsen sendiri ataupun penjual grosir, bila mereka melakukan distribusi dan penjualan langsung kepada konsumen.

Barang yang dijual di minimarket hampir menyerupai dengan barang yang dijual oleh warung tradisional. Dengan meningkatnya perkembangan minimarket dikhawatirkan berdampak pada kelangsungan usaha warung tradisional. Atas hal tersebut, maka untuk menjaga kelangsungan hidup usaha tradisional dibutuhkan strategi yang tepat. Strategi adalah proses manajerial untuk mengembangkan dan menjaga keserasian antara tujuan perusahaan, sumber daya perusahaan, dan peluang pasar yang terus berubah, dengan tujuan untuk membentuk dan menyesuaikan usaha perusahaan dan produk yang dihasilkan sehingga bisa mencapai keuntungan dan tingkat pertumbuhan yang menguntungkan (Kotler, 2008). Strategi dapat diartikan sebagai alat untuk mencapai tujuan jangka panjang. Strategi bisnis dapat mencakup ekspansi geografis, diversifikasi, akuisisi, pengembangan produk, penetrasi pasar, pengurangan bisnis, divestasi, likuidasi, dan joint venture.

Persaingan bisnis yang semakin ketat membuat pihak suatu perusahaan untuk menggunakan strategi yang tepat bagi produk atau jasa yang dijualnya. Pihak perusahaan harus mengamati kondisi persaingan bisnis yang selalu berkembang atau berubah setiap saatnnya. Persaingan adalah ketika organisasi atauperorangan berlomba untuk mencapai tujuan yang diinginkan seperti konsumen, pangsa pasar, peringkat survei, atau sumber daya yang dibutuhkan (Kuncoro, 2005).

Persaingan dalam kedua jenis pasar ini mendorong pemilik usaha untuk dapat terus meningkatkan efisiensi dan kualitas produk untuk dapat bersaing dengan toko ritel modern sehingga pelanggan merasa puas dengan produk tersebut. Selain itu persaingan usaha memiliki pengaruh positif terhadap pengembangan kreativitas sumber daya manusia untuk menggunakan sumber daya yang ada secara optimal dan menghasilkan barang-barang yang bernilai tinggi dengan harga yang kompetitif.

Pesatnya pertumbuhan toko modern di Indonesia ini menyebar diseluruh Wilayah, salah satunya adalah di Kota Medan. Kota Medan sendiri merupakan Kota Metropolitan, di mana penduduknya memilik berbagai macam usaha, salah satunya yaitu usaha bisnis ritel. Kota Medan terdiri dari beberapa kecamatan, salah satunya adalah Kecamatan Medan Helvetia. Di Kecamatan Medan Helvetia penduduknya sebagian melakukan penjualan warung tradisional. Hal inilah yang menjadi salah satu alasan peneliti melakukan penelitian mengenai persaingan usaha antara warung tradisional dengan toko modern pada daerah ini. Kecamatan Medan Helvetia dipilih sebagai lokasi penelitian ini karena Kecamatan Medan Helvetia merupakan salah satu Kecamatan di Kota Medan yang memiliki banyak warung tradisional dan juga toko modern. Di mana dari penelitian bertujuan untuk mengetahui apa saja faktor-faktor yang mempengaruhi persaingan antara warung tradisional dengan toko modern, sehingga bisa menjadi masukan bagi warung tradisional untuk bisa bertahan dengan usaha ritel warung tradisionalnya. 


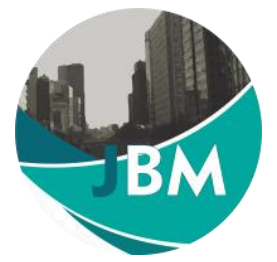

\section{Metode Penelitian}

Penelitian ini menggunakan metode deskriptif dengan pendekatan kualitatif. Penelitian ini digunakan untuk membangun sebuah pengetahuan melewati penemuan dan pemahaman dari lingkungan sekitar dan lingkungan yang diuji. Metode deskriptif digunakan untuk faktor- faktor apa saja yang dapat mempengaruhi persaingan usaha antara warung tradisional dengan toko modern. Pendekatan kualitatif digunakan untuk mendapatkan informasi yang lebih dalam terkait fenomena tersebut sehingga diperoleh penjelasan yang lebih komprehensif.

Data pada penelitian ini ada dua, yaitu data primer dan data sekunder. Pengumpulan data primer dilakukan dengan wawancara mendalam (in depth interview) dan Focus Group Discussion (FGD), sedangkan pengumpulan data sekunder diperoleh melalui bahan kepustakaan dan dokumen-dokumen. Informan penelitian diperoleh melalui teknik snowball (bola salju). Dari informan akan dimintakan untuk menunjuk informan berikutnya.

Analisis dilakukan secara simultan dengan proses pengumpulan data (on going analysis). Analisis kualitatif ini dilakukan mengikuti proses antara lain, reduksi data, penyajian data dan menarik kesimpulan berdasarkan reduksi dan penyajian data yang telah dilakukan sebelumnya. Reduksi data dilakukan untuk menggolongkan, membuang data yang tidak perlu, serta mengorganisasi data dengan cara sedemikian rupa hingga kesimpulankesimpulan akhirnya dapat ditarik dan diverifikasi. Penyajian data dilakukan untuk mengembangkan deskripsi informasi tersusun dari data yang sudah direduksi agar kemudian menarik kesimpulan dan pengambilan tindakan. Selanjutnya setelah data dikembangkan maka akan diperoleh kesimpulan dari penelitian yang sudah dilaksanakan.

Hasil

\section{Deskripsi Lokasi Penelitian}

Kecamatan Medan Helvetia adalah salah satu dari 21 kecamatan di kota Medan, Sumatera Utara, Indonesia. Kecamatan Medan Helvetia berbatasan dengan Medan Sunggal di sebelah barat, Medan Barat di timur, Medan Petisah di selatan, dan Medan Marelan di utara. Pada tahun 2001, kecamatan ini mempunyai penduduk sebesar 128.144 jiwa. Luasnya adalah 15,44 km².

\section{Perekonomian Di Kecamatan Medan Helvetia}

Sejumlah pasar dan pertokoan sudah mulai ramai mendukung kegiatan perekonomian di Kecamatan Medan Helvetia, diantaranya terdapat 3 pasar, 27 pertokoan, 34 minimarket dan 1 plaza (Badan Pusat Statistik Kota Medan 2020). Bisa dilihat perbandingan antara toko dengan toko modern hanya berbeda sedikit saja, toko odern lebih banyak dibanding toko biasa atau warung tradisional.

\section{Hal-Hal Yang Perlu Diperhatikan dalam Menghadapi Persaingan Usaha}

Tentunya di dalam persaingan usaha, ada beberapa hal yang perlu diperhatikan oleh para pemilik usaha untuk menghadapi persaingan. Beberapa hal yang perlu diperhatikan tersebut yaitu Harga, Lokasi, Pelayanan dan Kelengkapan Produk.

\section{Pentingnya Harga}

Harga mempengaruhi persaingan dalam pemasaran, selain itu harga juga mempunyai pengaruh terhadap pendapatan perusahaan secara langsung. Harga juga mampu mengkomunikasikan positioning nilai merek perusahaan, sehingga produk yang memiliki daya tawar dan dipasarkan dengan baik dapat dijual dengan harga tinggi sehingga menghasilkan keuntungan yang besar. Harga sebuah produk akan mempengaruhi program pemasaran perusahaan, selain itu harga akan merubah persepsi dimata konsumen. Konsumen mempunyai persepsi bahwa harga produk yang mahal memiliki kualitas produk yang baik, begitu sebaliknya harga produk yang murah memiliki kualitas produk yang buruk. Persepsi inilah yang menjadikan strategi penetapan harga yang tepat menjadi begitu penting.

Sebagai seorang pemilik usaha, seharusnya menyesuaikan harga dengan kualitas produk atau jasa yang ditawarkan, karena jika tidak sesuai antara harga yang ditawarkan dengan kualitas produk, maka kemungkinan konsumen tidak akan loyal terhadap perusahaan yang menawarkan harga tidak sesuai dengan produk. Ini salah satu hal penting juga yang diperhatikan dalam strategi penetapan harga, agar persepsi konsumen baik terhadap perusahaan kita. 
Biasanya calon konsumen akan mencari harga produk yang lebih murah untuk dijadikan langganan untuk membeli keperluan sehari-hari. Dengan begini, seorang pemilik usaha dalam hal ini warung tradisional harus pandai membuat strategi harga agar para pembeli menjadi loyal di warung tradisionalnya. Hal inilah yang diterapkan oleh para pemilik warung tradisional di Kecamatan Medan Helvetia, di tengah maraknya toko modern di Kota Medan khsusnya Kecamatan Medan Helvetia, yang tentunya akan menjadi pesaing bagi para pemilik warung tradisional, dengan menggunakan strategi harga yaitu dengan membuat harga di bawah harga produk pada toko modern, membuat para pembeli akhirnya banyak yang berlangganan pada warung tradisional tersebut. Jadi mereka lebih memilih warung tardisional dikarenakan harga pada warung tradisional lebih murah dibandingkan pada toko modern, walaupun toko modern untuk suasana lebih nyaman dengan ruangan ber AC, tapi para pembeli rata-rata lebih mempertimbangkan harga yang lebih murah, makanya mereka memilih warumg tradisional.

\section{Penentuan Lokasi Strategis}

Menurut Munawaroh (2013) salah satu strategi yang perlu diperhatikan oleh perusahaan adalah pemilihan lokasi, baik lokasi pabrik untuk perusahaan manufaktur ataupun lokasi usaha untuk perusahaan jasa/retail maupun lokasi perkantorannya. Pemilihan lokasi, diperlukan pada saat perusahaan mendirikan usaha baru, melakukan ekspansi usaha yang telah ada maupun memindahkan lokasi perusahaan ke lokasi lainnya.

Menurut Heizer \& Render (2015) lokasi adalah pendorong biaya dan pendapatan, maka lokasi seringkali memiliki kekuasanaan untuk membuat strategi bisnis perusahaan. Lokasi yang strategis bertujuan untuk memaksimalkan keuntungan dari lokasi baru perusahaan. Menurut Kotler (2008) Salah satu kunci menuju sukses adalah lokasi, lokasi dimulai dengan memilih komunitas. Keputusan ini sangat bergantung pada potensi pertumbuhan ekonomis dan stabilitas, persaingan, iklim politik, dan sebagainya.

Lokasi adalah letak, tempat atau penempatan suatu benda, keadaan pada permukaan bumi. Lokasi adalah tempat dimana orang-orang biasa berkunjung. Lokasi dalam hubungannya dengan pemasaran adalah tempat yang khusus dan unik di mana lahan tersebut dapat digunakan untuk berbelanja. Maka dapat disimpulkan bahwa lokasi yang dimaksud adalah suatu letak atau tempat yang tetap di mana orang biasa berkunjung untuk berbelanja, tempat itu berupa daerah pertokoan atau suatu stand di dalam maupun di luar gedung. Lokasi yang strategis mempengaruhi seseorang dalam menimbulkan keinginan untuk melakukan pembelian karena lokasinya yang strategis, terletak diarus bisnis, dan sebagainya. Keputusan tentang lokasi, baik untuk perusahaan manufaktur maupun perusahaan jasa biasa menentukan keberhasilan perusahaan. Kesalahan yang dibuat pada saat ini dapat menghambat efisiensi.

Lokasi usaha adalah hal utama yang perlu dipertimbangkan. Lokasi strategis menjadi salah satu factor penting dan sangat menentukan keberhasilan suatu usaha. Dalam memilih lokasi usahanya, pemilik lokasi usaha harus mempertimbangkan faktor-faktor pemilihan lokasi, karena lokasi usaha akan berdampak pada kesuksesan usaha itu sendiri.

Pemilihan lokasi sangat penting karena berkaitan dengan besar kecilnya biaya operasi, harga maupun kemampuan bersaing. Tujuan dari strategi bagi retail dan profesional service untuk maksimisasi revenue. Pemilihan lokasi retail dan profesional service yang mudah dijangkau konsumen memungkinkan terjadi penjualan dalam jumlah banyak, sehingga meningkatkan pendapatan perusahaan. Pemilihan lokasi usaha merupakan salah satu keputusan bisnis yang harus dibuat secara hati-hati.

Hal inilah yang dialami oleh pemilik warung tradisional di Kecamatan Medan Helvetia, di mana letak warung yang strategis menjadikan usaha mereka masih bertahan walaupun sudah banyaknya toko modern. Mereka sengaja memilih lokasi strategis, seperti di pinggir jalan besar, di persimpangan jalan, dan lain-lain, sehingga mudah dijangkau oleh para calon konsuemen.

Seperti yang disampaikan oleh Ibu Mutia, beliau menyatakan bahwa :

"Kebetulan lokasi warung kami di dekat pasar tradisional, makanya pengunjung hampir setiap hari ramai dan itu sangat berpengaruh terhadap warung kami, jadi Alhamdulillah pengunjung warung kami juga ramai setiap hari, jadi ya lokasi sangat mempengaruhi banyaknya pembeli berkunjung untuk membeli di warung ini".

Jadi mereka mengatakan jika lokasi sangatlah berpengaruh terhadap kesuksesan dan keberhasilan dan survive sampai sekarang ini walaupun sudah banyak toko modern yang berdiri.

\section{Pentingnya Kualitas Pelayanan}

Pelayanan konsumen adalah bentuk pemberian layanan atau servis yang diberikan kepada pelanggan atau konsumen. Persaingan yang semakin ketat sekarang ini, di mana semakin banyak produsen yang terlibat dalam 
pemenuhan kebutuhan dan keinginan pelanggan menyebabkan setiap perusahaan harus menempatkan orientasi kepada pemenuhan kepuasan pelanggan sebagai tugas utama. Pelayanan kepada pelanggan merupakan salah satu unsur terpenting dalam komunikasi pemasaran. Pelayanan kepada pelanggan bertujuan memelihara dan meningkatkan hubungan psikologis antara produsen dan pelanggan serta memantau barbagai keluhan pelanggan. Pelayanan dapat didefenisikan sebagai segala bentuk aktivitas yang diberikan oleh suatu pihak yang lain yang dapat memberikan kepuasan kepada pelanggan yang bersangkutan atas barang dan jasa yang diberikan.

Kualitas pelayanan adalah tingkat keunggulan yang diharapkan dan pengendalian atas tingkat keunggulan tersebut untuk memenuhi keinginan pelanggan" (Wykof dalam Arief, 2006). Schnaan berpendapat bahwa tujuan akhir dari suatu bisnis adalah mendapatkan keuntungan yang maksimal bagi perusahaan serta menciptakan kepuasan kepada para pelanggan. Oleh karena itu, hal terpenting yang harus dilakukan adalah memberikan pelayanan yang berkualitas sesuai dengan harapan konsumen atau pelanggan, sehingga pada dasarnya, kunci keberhasilan perusahaan-perusahaan yang menyelenggarakan jasa terletak pada kemampuan pelayanan pelanggan yang dapat memenuhi dan menjawab segala kebutuhan dan permasalahan pelanggan setiap saat, di manapun dan dalam kondisi apapun secara cepat dan tepat.

Pelayanan adalah usaha melayani kebutuhan orang lain. Pelayanan pada dasarnya adalah kegiatan yang ditawarkan oleh organisasi atau program kepada konsumen, yang bersifat tidak berwujud dan tidak dapat dimiliki. Pelayanan merupakan suatu kegiatan atau peroses yang berlangsung secara berkesinabungan atau terus menerus dalam interaksi antara seorang dengan orang lain dan menyedikan kepuasan pelanggan.

Begitu pentingnya pelayanan dilakukan karena berhubungan langsung dengan target utama, yaitu konsumen maka sangat perlu bagi pemilik usaha khususnya dalam hal ini pemilik warung tradisional. Jika pelayanan tidak bagus, maka kemungkinan besar para konsumen tidak akan berlangganan ke toko kita, itulah sebabanya pelayanan yang baik yang diperlukan agar menarik para pelanggan sehingga para konsumen bisa loyal terhadap perusahaan kita dalam hal ini warung tradisional.

Para pemilik warung tradisonal di Kecamatan Medan Helvetia, sangat tanggap terhadap para konsumennya, dan selalu cepat diladeni, ini salah satu yang mereka lakukan agar para konsumen tetap ingin berbelanja di warung mereka. Para karyawan juga ramah dan sopan serta jujur terhadap para pembeli, yang mana membuat para pembeli merasa nyaman dan akhirnya banyak yang berlangganan terhadap warung mereka. Seperti yang disampaikan oleh Bapak Akbar pemilik warung tradisional :

"kita melayani pembeli pastinya dengan sepenuh hati, walau kadang sudah lelah seharian, tapi kalo ada pembeli datang harus diladeni dengan sepenuh hati agar mereka betah berbelanja di warung ini, dan kadang ada pembeli yang suka bertanya, dan dengan senang hati akn kami tanggapi, ya tentunya tujuannya agar mereka nyaman berbelanja di warung kami,dan kalo mereka nyaman kan harapannya mereka akan terus-terusan berbelanja di warung kami, begitu"

Hal-hal yang dilakukan oleh para pemilih warung tradisional dalam memenuhi kualitas pelayanan yang baik agar para konsumen menjadi loyal terhadap warung mereka, yaitu (sesuai dengan pendapat Zeithami, Berry, dan Parasuraman (Lovelock, 2006) antara lain:

Reliability merupakan dimensi yang mengukur keandalan dari sisi perusahaan dalam memberikan pelayanan kepada pelanggan. Memberikan pelayanan dengan cepat dan tepat, dan selalu ada saat pelanggan membutuhkan bantuan. Pemilik warung tradisional di Kecamatan Medan Helvetia beserta para karyawan selalu berusaha memberikan memberikan pelayanan yang cepat dan tepat, dan juga tulus dalam membantu pelanggan, dan sigap dalam memenuhi permintaan pelanggan sehingga membuat pelanggan menjadi senang berbelanja pada warung tradisional tersebut. Responsiveness (ketanggapan)

Responsiveness adalah dimensi kualitas pelayanan yang dinamis. Harapan pelanggan terhadap kecepatan pelayanan. Warung tradisional pada Kecamatan Medan Helvetia selalu berusaha memberikan pelayanan yang cepat dan tepat, sehingga para konsumen tidak perlu menunggu terlalu laam untuk mendapatkan keinginan mereka.

Assurance (jaminan) Pengetahuan dan kemampuan para karyawan untuk menimbulkan kepercayaan dan rasa percaya diri dalam benak pelanggan. Warung tradisional pada Kecamatan Meda Helvetia ini berusaha 
membuat kepercayaan kepada para konsumen sehingga para konsumen nyaman dan betah berbelanja di warung tersebut.

Dari observasi di lapangan, ada beberapa warung tradisionl yang kelihatannya tidak ramah dan peneliti mencoba berbelanja ke warung tersebut tidak dilayani dengan baik, terlihat cuek, dan diminta untuk wawncara sebentar juga tidak bersedia dengan berbagai alasan, dan dari pemantauan, warung tersebut sangat sepi pengunjung. Inilh salah satu pentingnya pelayanan yang baik dan ramah terhadap para konsumen.

\section{Kelengkapan Produk}

Dalam usaha bisnis ritel tentunya salah satu yang dilihat oleh para konsumen adalah kelengkapan produk, ini sangat diperlukan agar para konsumen juga loyal berbelanja pada toko yang bersangkutan. Dari hasil survei ditemukan bahwa para konsumen sangat senang jika berbelanja di satu toko dan di toko tersebut lengkap barangbarang yang ingin dibelinya. Seperti yang dinyatakan oleh seorang konsumen yaitu Ibu Astuti, berikut kutipan wawancaranya :

"Saya berbelanja di warung ini karena barang yang saya inginkan biasanya selalu ada, jarang barang yang kosong, jadi karena barang yang ingin saya beli selalu ada, makanya saya tidak perlu bolak balik ke warung lain untuk membeli barang yang saya inginkan, cukup di warung ini saja".

Hampir senada dengan yang diucapkan oleh Bapak Putera, pemilik warung tradisional, beliau menyebutkan bahwa:

"Toko ini memang jarang barang kosong, karena selalu kami pantau, jika stock barang sudah mulai sedikit, kami akan membeli stock lagi, intinya jangan sampai kosong, dan jika kami kurang modal, maka kami akan bekerja sama dengan distributornya, jadi stock barang akan dimauskkan di toko kami, dan nantinya untung barang yang terjual akan dibagi 2 dengan pihak distributor, intinya jangan sampai stock barang kosong agar konsumen kami tidak kecewa".

Dari survei tersebut jelas terlihat begitu pentingnya kelengkapan produk agar para konsumen bisa loyal berbelanja di warung tersebut dan membuat konsumen tidak kecewa karena barang yang diinginkan selalu ada.

\section{Pembahasan}

Persaingan usaha yang terjadi sekarang ini menjadikan perusahaan selalu berusaha untuk memberikan jaminan bahwa produk yang ditawarkan mampu memberikan dukungan dalam upaya untuk menciptakan kepuasan konsumen. Berbagai upaya yang dilakukan yaitu melalukan berbagai inovasi produk yang ditawarkan sehingga produk atau jasa yang ditawarkan memiliki kualitas yang benar-benar mampu bersiang di pasar. Apabilka ditinjau dari segi konsumen, persiangan usaha yang terjadi akan memberikan dampak terhadapterhadap perilakunya sehingga konsumen selalu berupaya untuk mendapatkan produk yang terbaik sehingga dapat memenuhi segala bentuk kebutuhannya. Tentunya ada faktor-faktor yang mempengaruhi persaingan usaha ini. Di mana, faktor-faktor yang mempengarui persaingan antara warung tradisional dengan toko modern adalah sebagai berikut:

Harga adalah nilai suatu barang atau jasa yang diukur dengan jumlah uang yang dikeluarkan oleh pembeli untuk mendapatkan sejumlah kombinasi danbarang atau jasa berikut pelayanannya. Jadi biasanya seorang calon pembeli akan melihat harga dari prudk yang akan dia beli. Biasanya calon konsumen akan mencari harga produk yang lebih murah untuk dijadikan langganan untuk membeli keperluan sehari-hari. Dengan begini, seorang pemilik usaha dalam hal ini warung tradisional harus pandai memuat strategi harga agar para pembeli menjadi loyal di warung tradisionalnya. Sesuai dnegan pendapat Tjiptono (2009) bahwa harga mempunyai peranan penting bagi konsumen dalam penjualan ritel di mana ada segmen pembeli yang sangat sensitif terhadap faktor harga (menjadikan harga sebagai satu-satunya pertimbangan membeli produk) dan ada pula yang tidak. Mayoritas konsumen agak sensitif terhadap harga, namun juga mempertimbangkan faktor lain (seperti cira merek, lokasi toko, pelayanan, nilai, dan kuaitas).

Hal inilah yang diterapkan oleh para pemilik warung tradisional di Kecamatan Medan Helvetia, di tengah maraknya toko modern di Kota Medan khsusnya Kecamatan Medan Helvetia, yang tentunya akan menjadi pesaing bagi para pemilik warung tradisional, dengan menggunakan strategi harag yaitu dengan membuat harga di bawah harga produk pada toko modern, membuat para pembeli akhirnya banyak yang berlangganan pada warung tradisional tersebut. Mereka lebih memilih warung tardisional dikarenakan harga pada warung tradisional lebih 


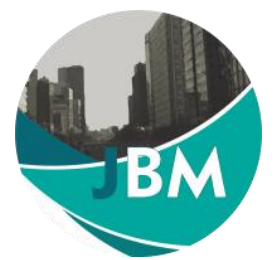

Jurnal Bisnis dan Manajemen

http://jurnal.unmer.ac.id/index.php/jbm/index
Volume 8 No 1

2021

HIm. 91 - 98

murah dibandingkan pada toko modern, wllaupun toko modern untuk suasan lebi nyaman dengan ruangan ber AC, tapi para pembeli rata-rata lebih mempertimbangkan harga yang lebih murah, makanya mereka memilih warumg tradisional.

Kedua adalah lokasi atau letak, tempat atau penempatan suatu benda, keadaan pada permukaan bumi. Lokasi adalah tempat dimana orang-orang biasa berkunjung. Menurut Heizer \& Render (2015) lokasi adalah pendorong biaya dan pendapatan, maka lokasi seringkali memiliki kekuasanaan untuk membuat strategi bisnis perusahaan. Lokasi yang strategis bertujuan untuk memaksimalkan keuntungan dari lokasi bari perusahaan. Sedangkan menurut Kotler (2008) Salah satu kunci menuju sukses adalah lokasi,lokasi dimulai dengan memilih komunitas.

Dalam hubungannya dengan pemasaran adalah tempat yang khusus dan unik di mana lahan tersebut dapat digunakan untuk berbelanja. Maka dapat disimpulkan bahwa lokasi yang dimaksud adalah suatu letak atau tempat yang tetap di mana orang bias berkunjung untuk berbelanja, tempat itu berupa daerah pertokoan atau suatu stand di dalam maupun di luar gedung. Lokasi yang strategis mempengaruhi seseorang dalam menimbulkan keinginan untuk melakukan pembelian karena lokasinya yang strategis, terletak diarus bisnis, dan sebagainya. Keputusan tentang lokasi, baik untuk perusahaan manufaktur maupun perusahaan jasa bias menentukan keberhasilan perusahaan. Kesalahan yang dibuat pada saat ini dapat menghambat efisiensi. Seleksi lokasi untuk perusahaan barang atau manufaktur perlu lebih dekat kebahan baku atau tenaga kerja, sedangkan untuk perusahaan jasa perlu lebih dekat dengan pelanggan.

Lokasi usaha adalah hal utama yang perlu dipertimbangkan. Lokasi strategis menjadi salah satu factor penting dan sangat menentukan keberhasilan suatu usaha. Dalam memilih lokasi usahanya, pemilik lokasi usaha harus mempertimbangkan faktor-faktor pemilihan lokasi, karena lokasi usaha akan berdampak pada kesuksesan usaha itu sendiri. Hal inilah yang dialami oleh pemilik warung tradisional di Kecamatan Medan Helvetia, di mana letak warung yang strategis menjadikan usaha mereka masih bertahan walaupun sudah banyaknya toko modern. Mereka sengaja memilih lokasi strategis, seperti di pinggri jalan besar, di persimpangan jalan, dan lain-lain, sehingga mudah dijangkau oleh para calon konsumen. Hal ini sesui dnegan pendapat Munawaroh (2013) salah satu strategi yang perlu diperhatikan oleh perusahaan adalah pemilihan lokasi, baik lokasi pabrik untuk perusahaan manufaktur ataupun lokasi usaha untuk perusahaan jasa/retail maupun lokasi perkantorannya. Pemilihan lokasi, diperlukan pada saat perusahaan mendirikan usaha baru, melakukan ekspansi usaha yang telah ada maupun memindahkan lokasi perusahaan ke lokasi lainnya. Jadi mereka mengatakan jika lokasi sangatlah berpengaruh terhadap kesuksesan dan keberhasilan dan survive di sampai sekarang ini walaupun sudah banyak toko modern.

Ketiga adalah pelayanan, yaitu usaha melayani kebutuhan orang lain. Pelayanan pada dasarnya adalah kegiatan yang ditawarkan oleh organisasi atau program kepada konsumen, yang bersifat tidak berwujud dan tidak dapat dimiliki. Pelayanan merupakan suatu kegiatan atau peroses yang berlangsung secara berkesinabungan atau terus menerus dalam interaksi antara seorang dengan orang lain dan menyedikan kepuasan pelanggan.Begitu pentingnya pelayanan dilakukan karena berhubungan langsung dengan target utama, yaitu konsumen maka sangat perlu bagi pemilik usaha khususnya dalam hal ini pemilik warung tradisional. Jika pelayanan tidak bagus, maka kemungkinan besar para konsumen tidak akan berlanggann ke toko kita, itulah sebabanya pelayanan yang baik yang diperlukan agar menarik para pelanggan.

Para pemilik warung tradisonal di Kecamatan Meda Helvetia, sangat tanggap terhadap para konsumennya, dan selalu cepat dilayani, ini salah satu yang mereka lakukan agar para konsumen tetap ingin berbelanja di warung mereka. Para karyawan juga ramah dan sopan serta jujur terhadap para pembeli, yang mana membuat para pembeli merasa nyaman dan akhirnya banyak yang berlangganan terhadap warung mereka. Hal ini sesui dnegan teori Parasuraman, Berry dan Zeithhalm (1998) yang menytaakan bahwa Pelanggan akan merasa puas apabila yang mereka peroleh adalah pelayanan yang baik atau pelayanan yang sesuai dengan harapkan mereka.

Terakhir adalah kelengkapan produk. Tentunya suatu hal yang sangat diperlukan dalam bisnis ritel. Jika produk yang diinginkan pada suatu toko yang dituju ada dan lengkap, biasanya konsumen akan suka dengan toko tersebut, dan biasanya jika ingin membeli barang, akan kembali ke toko tersebut dikarenakan pernah membeli tidak kecewa karena barang yang diinginkan selalu ada yang membuat konsumen akhirnya loyal. Inilah kenapa kelengkapan produk merupakan salah satu yang diperlukan dalam persaingan usaha dalam hal ini bisnis ritel warung tradisional. 
Para pemilik warung tradisional di Kecamatan Medan Helvetia, berusaha melengkapi tokonya agar para konsumen bisa berlangganan ke toko mereka, dan jika mereka kekurangan modal, maka mereka akan bekerja sama dengan distributor untuk menjualkan produknya dan untungnya akan dibagi 2 , ini cara yang mereka lakukan untuk menutupi kekosongan stock

\section{Kesimpulan}

Berdasarkan hasil penelitian, maka dapat diketahui dan disimpulkan bahwa faktor-faktor yang dapat mempengaruhi persaingan usaha antara warung tradisional dengan toko modern adalah harga, lokasi, dan pelayanan. Para pemilik warung tradisional di Kecamatan Medan Helvetia, membuat strategi harga yaitu dengan membuat harga di bawah harga produk pada toko modern, membuat para pembeli akhirnya banyak yang berlangganan pada warung tradisional tersebut. Mereka lebih memilih warung tardisional dikarenakan harga pada warung tradisional lebih murah dibandingkan pada toko modern.

Lokasi usaha adalah hal utama yang perlu dipertimbangkan. Lokasi strategis menjadi salah satu faktor penting dan sangat menentukan keberhasilan suatu usaha. Dalam memilih lokasi usahanya, pemilik lokasi usaha harus mempertimbangkan faktor-faktor pemilihan lokasi, karena lokasi usaha akan berdampak pada kesuksesan usaha itu sendiri. Hal inilah yang dialami oleh pemilik warung tradisional di Kecamatan Medan Helvetia, di mana letak warung yang strategis menjadikan usaha mereka masih bertahan walaupun sudah banyak toko modern. Mereka sengaja memilih lokasi strategis, seperti di pinggir jalan besar, di persimpangan jalan, dan lain-lain, sehingga mudah dijangkau oleh para calon konsumen dan juga di area pasar tradisonal.

Slanjutnya adalah pelayanan. Begitu pentingnya pelayanan dilakukan karena berhubungan langsung dengan target utama, yaitu konsumen maka sangat perlu bagi pemilik usaha khususnya dalam hal ini pemilik warung tradisional. Para pemilik warung tradisonal di Kecamatan Meda Helvetia, sangat tanggap terhadap para konsumennya, dan selalu cepat diladeni, ini salah satu yang mereka lakukan agar para konsumen tetap ingin berbelanja di warung mereka.

\section{Daftar Pustaka}

Arief, M. (2006). Pemasaran Jasa Dan Kualitas Pelayanan. Malang: Banyu Media Publishing

Fandy, Tjiptono. (2009). Strategi Pemasaran, edisi kedua, cetakan ketujuh, Yogyakarta: Andi Offset

H. Lovelock Christoper \& Laurent K. Wright. (2005). Manajemen Pemasaran Jasa. Jakarta: PT Indeks Kelompok Gramedia

Heizer, Jay and Render Barry. (2015). Manajemen Operasi : Manajemen Keberlangsungan dan Rantai Pasokan, edisi 11. Jakarta: Salemba Empat

I Gusti Agung \& Ayu Rai Yudhi Astiti. (2016). Analisis Faktor Ketahanan Pedagang Warung Tradisional Menghadapi Pesaing Minimarket Di Kabupaten Badung. Jurnal Buletin Studi Ekonomi ,Vol. 21, No 2. Fakultas Ekonomi dan Bisnis, Universitas Udayana.

Kotler, Philip. (2008). Manajemen Pemasaran. Jakarta: Indeks

Kotler, Philip; Armstrong, Garry. (2008). Prinsip-prinsip Pemasaran,Jilid 1. Jakarta: Erlangga

Mahrani Rangkuti. (2018). Pengaruh Kehadiran Toko Modern Terhadap Keberlangsungan Warung Tradisional Di Kota Padangsidimpuan. Jurnal Esturpo, Vol.3 No.2 Mei-Agustus

Mudrajad, Kuncoro. (2005). Strategi Bagaimana Meraih Keunggula Kompetitif. Jakarta: Erlangga

Munawaroh, Munjiati. (2013). Manajemen Operasi. Yogyakarta: LP3M UMY.

Parasuraman, A., Zeithaml V.A., and Berry,L.L . (1998). SERVQUAL: amultiple item scale for Measuring consumer perceptions of service quality, Journal of Retaling, Vol.64,No,1

Reza, Haditya Raharjo. (2015). Analisis Pengaruh Keberadaan Minimarket Modern Terhadap Kelangsungan Usaha Toko Kelontong Di Sekitarnya (Studi Kasus Kawasan Semarang Barat, Banyumanik). Semarang: Fakultas Ekonomi, Universitas Diponegoro.

Rival, Nursema. (2018). Pengaruh Perkembangan Minimarket Terhadap Kelangsungan Usaha Warung Tradisional Dan Strategi Agar Dapat Bersaing Dan Bertahan Hidup Di 3 Kecamatan Kota Tangerang Selatan. Jakarta: Fakultas Ekonomi dan Bisnis, Universitas Islam Negeri Syarif Hidayatullah Jakarta 
Sutikno, MS. (2009). Belajar dan Pembelajaran, Upaya Kreatif dalam Meuwujdkan Pembelajaran yang Berhasil. Bandung: Prospect

Tambunan, Tulus TH. (2004). Kajian Persaingan dalam Industri Retail. Komisi Pengawas Persaingan Usaha (KPPU).

Tri Joko Utomo. (2011). Persaingan Bisnis Ritel: Tradisional VS Modern (The Competition of Retail Business: Traditional vs Modern)). Jurnal: Fokus Ekonomi, Vol.6, No.1

Utami, Christina Widya. (2006). Manajemen Ritel. Jakarta: Salemba Empat.

Utami, Christina Widya. (2008). Manajemen Ritel (strategi dan implementasi ritel modern. Jakarta: Salemba Empat.

Welem, Anthonie Bawole. (2017). Respons Pemilik Warung Kecil Terhadap Kehadiran Usaha Waralaba Di Kelurahan Tuminting Kecamatan Tuminting Kota Manado, E-Journal Acto Diurna, Vol.Vi, No.3 